\title{
Lipid biomarkers reveal geographical differences in food supply to the cold-water coral Lophelia pertusa (Scleractinia)
}

\author{
L. A. Dodds ${ }^{1,3}$, K. D. Black ${ }^{1}$, H. Orr ${ }^{1}$, J. M. Roberts ${ }^{1,2,4, *}$ \\ ${ }^{1}$ Scottish Association for Marine Science, Dunstaffnage Marine Laboratory, Oban PA37 1QA, UK \\ ${ }^{2}$ Center for Marine Science, University of North Carolina Wilmington, 5600 Marvin K. Moss Lane, \\ Wilmington, North Carolina 28409, USA \\ ${ }^{3}$ Present address: WWF, Baltic House, Mount Stuart Square, Cardiff CF10 5FH, UK \\ ${ }^{4}$ Present address: Centre for Marine Biodiversity \& Biotechnology, School of Life Sciences, Heriot-Watt University, \\ Edinburgh, EH14 4AS, UK
}

\begin{abstract}
Despite its importance as an ecological engineer, little is known about the feeding ecology of the widespread reef framework-forming cold-water coral Lophelia pertusa. This is the first study to compare lipid signatures of $L$. pertusa from different areas in the North Atlantic using samples from 2 sites in the eastern Atlantic and 2 seamounts in the western Atlantic. Lipid samples were collected in February, May, July and November from the Mingulay reef complex off western Scotland, but no clear seasonal pattern was observed. High lipid content and large wax ester fractions were recorded from all sites, with the highest values recorded at the shallowest site (Mingulay). Here the prevalence of copepod lipid biomarkers - monounsaturated fatty acids 20:1(n-9) and 22:1(n-11) and their fatty alcohols - indicates $L$. pertusa feeds predominantly on calanoid copepods. At deeper offshore sites, the abundance of the fatty acid 18:1(n-9) and fatty alcohol 16:0 suggest a significant dietary input from non-calanoid copepods. Our results imply that the shallow Mingulay site is likely to receive a greater input of fresh surficial material and a higher abundance of herbivorous calanoid copepods, while at the deeper sites, carnivorous or omnivorous non-calanoid copepods are likely to be more abundant. $L$. pertusa therefore appears to be an opportunistic feeder capable of taking a variety of zooplankton prey. Further investigation is required to assess site-specific dependence on prey sources.
\end{abstract}

KEY WORDS: Deep-sea coral · Ecosystem engineer - Fatty acid · Feeding · Trophic level · Copepods $\cdot$ MUFA $\cdot$ PUFA

Resale or republication not permitted without written consent of the publisher

\section{INTRODUCTION}

Little is known of the feeding ecology of cold-water corals, despite their widespread distribution and increased scientific interest in recent years (Roberts et al. 2006, 2009). Lophelia pertusa (Linnaeus 1758) is the most widespread reef framework-forming cold-water coral. It is generally found at water depths between 200 and 1000 m, making observational work difficult. However, submersible observations have shown $L$. pertusa feeding on live zooplankton (Henrich \& Freiwald 1997), and laboratory experiments have shown it can feed on calanoid copepods and semi-pelagic crustaceans (Mortensen et al. 2001, Roberts \& Anderson 2002). This suggests that L. pertusa is supported by surface production (Duineveld et al. 2004) rather than a chemosynthetic food chain, with recent spatial meta-analysis showing that cold-water corals are associated with areas where surface waters show above average primary productivity (Guinotte et al. 2006, Davies et al. 2008). 
Fatty acid analysis has been used to determine prey species and trophic links for a number of marine organisms (e.g. Lee et al. 1971, Falk-Petersen et al. 1987, Graeve et al. 1997, Best et al. 2003), and is particularly useful for deep-sea organisms due to the challenge and expense of observational studies and the increased likelihood that ingested food will be expelled by animals collected at great depths (Feller et al. 1985). The fatty acid trophic marker technique is based on the premise that primary producers have a specific fatty acid signature that is transferred to primary consumers, and thence up the food chain, being modified at every step, but retaining a significant amount of information between steps (Dalsgaard et al. 2003, Iverson et al. 2004). However, it is possible that some fatty acids are biosynthesised or modified by the organism rather than transferred from food sources, as observed in studies on fatty acids in urchin gonads (Cook et al. 2000, Kelly et al. 2008).

As well as in the study of trophic interactions and the relative importance of prey items, fatty acid analysis has also been used to assess spatial variations in lipid signatures. For example, differences in the fatty acid signature of Antarctic krill Euphausia superba between areas were attributed largely to variations in algal biomass and likely dependence on polyunsaturated fatty acid (PUFA)-rich copepods (Cripps et al. 1999). In New Zealand, fatty acid differences in the green-lipped mussel Perna canaliculus between areas have been linked to changes in phytoplankton composition between 2 areas with differences in water temperature (Taylor \& Savage 2006). Fatty acid techniques have also been used to study abyssal asteroid echinoderms where fatty acid signatures appeared to be directly related to species-specific feeding modes. Suspension-feeding species have a signature with high levels of PUFA, suggesting dependence on surface production (Howell et al. 2003). Many PUFA are synthesised de novo by phytoplankton and are highly conserved in herbivorous zooplankton (Sargent \& Whittle 1981, Dalsgaard et al. 2003). PUFA are labile and tend to arrive in the deep-sea in the summer months, following spring blooms of phytoplankton, and are deposited in fresh organic matter. High proportions of PUFA were identified in some species of deep-sea holothurians, suggesting a close link to surface production (Hudson et al. 2004). Since PUFA are present in both phytoplankton and zooplankton, their presence alone cannot be used to determine the dietary source. Copepod species tend to store large quantities of lipids, mainly in the form of wax esters, and their presence, along with specific long-chain fatty alcohols within this fraction, strongly suggest copepods as a prey item when observed in an organism's lipid profile (Lee et al. 1971, Kattner \& Hagen 1995).
The majority of studies of lipid signatures in corals and anemones have focused on shallow-water zooxanthellate species. Shallow-water corals and anemones are relatively lipid-rich, with large stores of wax esters and triglycerides (Patton et al. 1977, Harland et al. 1991, Harland et al. 1993, Yamashiro et al. 1999). The accumulated wax esters are thought to be used in times of low food input, indicating a variable food supply (Lee et al. 1971, Falk-Petersen et al. 1981, Sargent \& Falk-Petersen 1988). In endosymbiotic species, the fatty acids synthesised by zooxanthellae are mainly saturated fatty acids (SFA), which are transferred to the host in glycerol droplets (Patton et al. 1983). PUFA are also present in coral lipids and are thought to originate from external food sources, such as plankton, indicating the level of heterotrophy (Meyers 1979). More recent studies have found that zooxanthellae are able to synthesize PUFA and it is possible that they could be transferred to their hosts (Papina et al. 2005, Treignier et al. 2008). However, a greater proportion of unsaturated fatty acids are found in azooxanthellate compared with zooxanthellate species (Patton et al. 1983, Latyshev et al. 1991, Yamashiro et al. 1999), suggesting that the majority of PUFA originate from external food sources. The relative proportion of PUFA also increases with depth, possibly suggesting a greater reliance on heterotrophic feeding at depth, although the effect of temperature on PUFA content has yet to be established (Yamashiro et al. 1999). The recorded $\delta^{13} \mathrm{C}$ values for zooxanthellate tropical coral tissue also show a change with depth, indicating a greater reliance on carbon from external sources rather than from zooxanthellae symbionts (Muscatine et al. 1989), although this has been shown to be influenced by other parameters including light (Reynaud-Vaganay et al. 2001, Omata et al. 2008).

Compared with zooxanthellate shallow-water corals, azooxanthellate corals, especially those found in deeper, colder waters, have been less studied but some relevant studies have recently been completed. Mancini et al. (1999) identified novel hydroxypolyenoic acids in Lophelia pertusa and Madrepora oculata. Another study of these 2 species compared their fatty acid signature to that of suspended particulate organic matter (sPOM) (Kiriakoulakis et al. 2005). The corals had higher levels of monounsaturated fatty acids (MUFA) and fatty alcohols than the sPOM, suggesting a mesozooplankton food source. However, Kiriakoulakis et al. (2005) did not separate the lipids of cold-water corals into different classes. Studies at Galicia Bank and Rockall Bank recorded daily, seasonal and annual variations in phytodetritus and carbon flux to areas where L. pertusa occurs (Duineveld et al. 2004, 2007). The results from Galicia Bank suggested that the corals might feed on a mixed diet of phytode- 
tritus and zooplankton, whereas $\delta^{15} \mathrm{~N}$ analysis at Rockall Bank revealed values similar to obligate filter feeders (Duineveld et al. 2004, 2007).

The aims of the present study were to quantify the major lipid classes in Lophelia pertusa and to identify the constituent fatty acids and alcohols to better understand likely food sources. Although previous studies have used $\delta^{15} \mathrm{~N}$ analysis to estimate trophic level and have compared coral lipids to SPOM, detailed analysis of geographical variation in lipid content and signature has not yet been attempted. Here we compare the lipid signatures of $L$. pertusa between different areas: a relatively shallow inshore site, the Mingulay reef complex; a deeper coral carbonate mound on Rockall Bank; and seamounts off the eastern coast of the USA. This represents the most detailed study to date of the lipid and fatty acid composition of $L$. pertusa and is the first to draw seasonal and geographical comparisons.

\section{MATERIALS AND METHODS}

Study sites. The lipid signature of 38 samples of Lophelia pertusa from 3 different geographical areas was analysed. A total of 17 samples were collected from an average depth of approximately $130 \mathrm{~m}$ at the Mingulay reef complex (Roberts et al. 2005, this
Theme Section). The Mingulay reefs are in the Sea of the Hebrides, which separates the Scottish mainland from the Outer Hebrides $\left(56^{\circ} 49.38^{\prime} \mathrm{N}, 7^{\circ} 22.56^{\prime} \mathrm{W}\right.$, Fig. 1). Samples were collected from the Mingulay reefs at different times of the year to determine seasonal difference in lipid signature. The RV 'Calanus' was used to collect samples in February $(n=3)$ and November ( $\mathrm{n}=4)$ 2005, the MY 'Esperanza' in May 2005 ( $n=5)$, while samples from July 2006 ( $n=5)$ were collected onboard the RV 'Pelagia' (Duineveld et al. 2006). Thirteen samples were collected in June 2006 from a deeper water site on the Rockall Bank, west of the UK, in the Logachev Mounds region at depths of approximately $900 \mathrm{~m}$ (Kenyon et al. 2003, Masson et al. 2003, van Weering et al. 2003, White et al. 2005) (Fig. 1). Finally, 8 samples were also collected in August 2005 from 2 seamounts in the New England Seamount chain: Manning $\left(38^{\circ} 20.00^{\prime} \mathrm{N}, 60^{\circ} 40.00^{\prime} \mathrm{W}\right)$ and Rehoboth $\left(37^{\circ} 20.00^{\prime} \mathrm{N}, 60^{\circ} 00.00^{\prime} \mathrm{E}\right)$, rising to water depths of 1312 and $1217 \mathrm{~m}$, respectively (Fig. 1). The New England samples were collected from the RV 'Ronald H. Brown' using the ROVs 'Hercules' and 'Argus'. Mingulay samples were collected using a video-directed van Veen grab and Rockall Bank samples were collected by box corer. Samples were stored on the ship at $-20^{\circ} \mathrm{C}$ before being returned to the laboratory (within $12 \mathrm{~d}$ ), where they were freeze-dried at

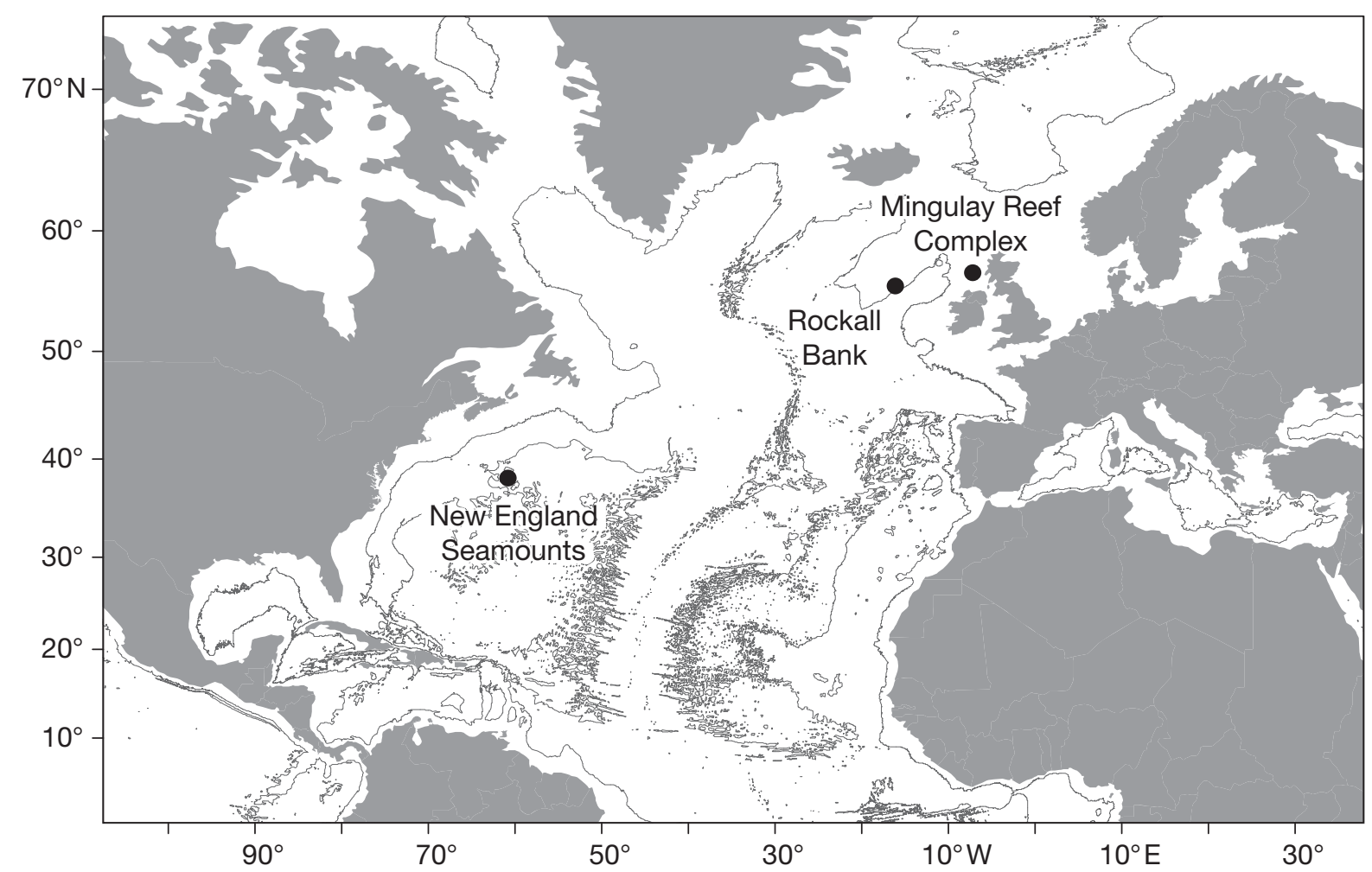

Fig. 1. Study sites in the North Atlantic: New England Seamounts (1217 m and $1312 \mathrm{~m}$ water depth), Rockall Bank (900 m) and the Mingulay reef complex (130 m) 
$-60^{\circ} \mathrm{C}$ and then stored at $-20^{\circ} \mathrm{C}$ before analysis (for up to $8 \mathrm{mo}$ ). Hydrolysis has been shown to occur when samples are frozen and stored for long periods (Ohman 1996); in the present study, samples were freeze-dried within $12 \mathrm{~d}$ of collection in order to reduce the possibility of hydrolysis.

Lipid extraction and fatty acid analysis. Coral polyp material ( 5 g) was broken from each sample, ground and a portion $(3 \mathrm{~g})$ analysed for lipids. The remaining portion $(2 \mathrm{~g})$ was used to determine ash-free dry mass (AFDM) by placing in a muffle furnace (Nabertherm Controller B170) at $500^{\circ} \mathrm{C}$ for $4.5 \mathrm{~h}$. The difference in mass before and after combustion gave the AFDM. Lipids were extracted, separated and analysed by standard methods (see online supplementary material) in order to study the major storage lipid classes: wax esters and triglycerides. Briefly, the lipids were extracted in chloroform:methanol, wax esters and triglycerides separated by thin-layer chromatography (TLC), both fractions were transesterified to give fatty acid methyl esters (FAME) and the wax ester fraction silylated to give the trimethysilyl ethers of the fatty alcohol components. Wax ester and triglyceride fraction derivatives were each separated by gas chromatography (GC), identified on the basis of standard retention times, and quantified with respect to the internal standards added to the initial lipid extract and subsequent fractions. Where in doubt, double bond position was established by GC-MS of 4,4-dimethyloxazoline (DMOX) derivatives (Spitzer 1996).

Statistical analysis. The proportions and weights of total storage lipids (wax esters plus triglycerides) and their fatty alcohol and fatty acid components were compared geographically, and seasonally for the Mingulay samples, using the non-parametric KruskalWallis test. In order to compare the relative proportions of the FAME and fatty alcohols in the 2 separate fractions geographically and seasonally (Mingulay samples), multivariate analysis was carried out using PRIMER version 6. Following the approach of Howell et al. (2003), the data were not transformed to avoid attributing excessive weighting to fatty acids with a low contribution to the signature. Bray-Curtis similarity matrices were created and multidimensional scal- ing (MDS) plots were used to visualise the similarity in patterns of fatty acid signature between months at Mingulay and geographical areas. In an MDS plot, the samples with the greatest similarity cluster together in 2-dimensional space, while the samples that are least similar are widely spaced. The differences between months and areas were identified using analysis of similarity (ANOSIM) before similarity percentage routines (SIMPER) were used to identify the fatty acids contributing to the observed differences.

\section{RESULTS}

\section{Seasonal differences in lipid signature at Mingulay}

The wax esters were the largest fraction in all months. There were no significant differences in weights of the total storage lipids (Kruskal-Wallis, $H=$ $6.51, \mathrm{df}=3, \mathrm{p}=0.089)$, the wax ester fraction $(H=6.82$, $\mathrm{df}=3, \mathrm{p}=0.077)$ or the triglyceride fraction $(H=6.55$, $\mathrm{df}=3, p=0.088$ ) between months. Analysis of the relative proportions of the FAME and fatty alcohols in the wax ester fraction (ANOSIM, r $=0.057, \mathrm{p}=0.285$ ) and triglyceride fraction $(\mathrm{r}=0.168, \mathrm{p}=0.057)$ revealed no significant difference between months (Tables S1 \& S2, in Supplement 1 available at: www.int-res.com/ articles/suppl/m397p113_app.pdf). Therefore, subsequent analysis of geographical differences used Mingulay samples pooled from all 4 mo and compared relative abundances of the lipid signature.

\section{Geographical variations in lipid signature}

The total amount of storage lipids ( $\mathrm{mg} \mathrm{g}^{-1}$ ) varied between New England, Rockall and Mingulay samples (Kruskal-Wallis, $H=13.46, \mathrm{df}=2, \mathrm{p}<0.001$ ), with Mingulay samples having the highest values (Table 1$)$. The total weight of the wax ester $(H=13.62, \mathrm{df}=2, \mathrm{p}<$ $0.001)$ and the triglyceride fractions $(H=8.43, \mathrm{df}=2, \mathrm{p}$ $<0.05$ ) also varied between areas with the highest values found in the Mingulay samples. Wax esters were the largest fraction in all areas.

Table 1. Lophelia pertusa. Mean values $( \pm \mathrm{SD})$ for wax esters and triglycerides $\left(\%\right.$ storage lipid, weight in $\mathrm{mg}^{-1}$ tissue dry weight) in samples collected from New England Seamounts, Rockall Bank and the Mingulay reef complex

\begin{tabular}{|lccccc|}
\hline \multirow{2}{*}{ Site } & $\mathrm{n}$ & \multicolumn{2}{c|}{ Wax ester } & \multicolumn{2}{c|}{ Triglyceride } \\
\cline { 3 - 4 } & & $\begin{array}{c}\text { Storage lipid } \\
\text { (\%) }\end{array}$ & $\begin{array}{c}\text { Weight } \\
\left(\mathrm{mg} \mathrm{g}^{-1}\right)\end{array}$ & $\begin{array}{c}\text { Storage lipid } \\
(\%)\end{array}$ & $\begin{array}{c}\text { Weight } \\
\left(\mathrm{mg} \mathrm{g}^{-1}\right)\end{array}$ \\
\hline New England & 8 & $57.02 \pm 6.98$ & $32.09 \pm 18.96$ & $42.98 \pm 6.98$ & $22.58 \pm 8.56$ \\
Rockall & 13 & $62.01 \pm 8.10$ & $41.96 \pm 28.08$ & $37.99 \pm 8.10$ & $25.05 \pm 20.15$ \\
Mingulay & 17 & $68.54 \pm 6.62$ & $87.18 \pm 52.44$ & $31.46 \pm 6.62$ & $37.18 \pm 19.37$ \\
\hline
\end{tabular}


The predominant FAME within the triglyceride fraction of all samples was 16:0, followed by 20:5(n-3) (Table S3, in Supplement 1 available at: www.intres.com/articles/suppl/m397p113_app.pdf). Some differences appeared between areas with 18:1(n-9) and 20:4(n-6) the next most dominant FAME in the New England and Rockall samples, compared to the Mingulay samples where 22:1(n-11) and 20:1(n-9) were the next most dominant FAME. PUFA were the dominant category and the PUFA/MUFA ratio was similar between all 3 areas. The 22:6(n-3)/20:5(n-3) ratio was also similar between areas. The 18:1(n-9)/18:1(n-7) ratio was higher in both the New England and Rockall samples than the Mingulay samples.

The predominant FAME and fatty alcohols in the wax ester fraction of the samples were similar between New England and Rockall (Table S4, in Supplement 1 available at: www.int-res.com/articles/suppl/ m397p113_app.pdf). The dominant FAME was 18:1 (n-9) followed by the fatty alcohols 16:0 and 22:1, in contrast to the Mingulay samples where the dominant wax ester components were the FAME 22:1 and the fatty alcohols 20:1 and 22:1 (Table S4). The MUFA component formed the majority of the wax ester fraction in the samples from New England, Rockall and Mingulay. The 22:6(n-3)/20:5(n-3) ratio was lowest in the Mingulay samples.

The MDS plots for the samples from different geographical areas show distinct separation in the relative proportions of FAME and fatty alcohols between areas for the wax ester fraction (Fig. 2a), a pattern most pronounced for the Mingulay samples. There is also some separation between the Rockall and New England samples. The MDS plot for the triglyceride fraction shows less separation in relative proportions of FAME for the different areas, although Mingulay samples are again distinct (Fig. 2b). The New England and Rockall samples overlap implying similarities between these 2 areas.

ANOSIM revealed significant differences in the fatty acid signature from different areas in the wax ester $(\mathrm{r}=0.862, \mathrm{p}<0.01)$ and triglyceride fractions $(\mathrm{r}=0.603$, $\mathrm{p}<0.01)$. Pairwise analysis of the data showed that there were differences between the New England and Rockall samples and the Mingulay samples in both the wax ester and the triglyceride fractions, and differences between New England and Rockall samples in the wax ester fraction (Table 2). The fatty acids/alcohols contributing to the observed differences between areas were identified using SIMPER analysis. The FAME 18:1(n-9), 22:1 and 20:5(n-3) and the fatty alcohols 22:1, 20:1 and 16:0 were the major contributors to the differences between all 3 areas (Table 3). In all cases the differences observed were caused by a large number of fatty acids and alcohols.
Resemblance: S17 Bray Curtis similarity
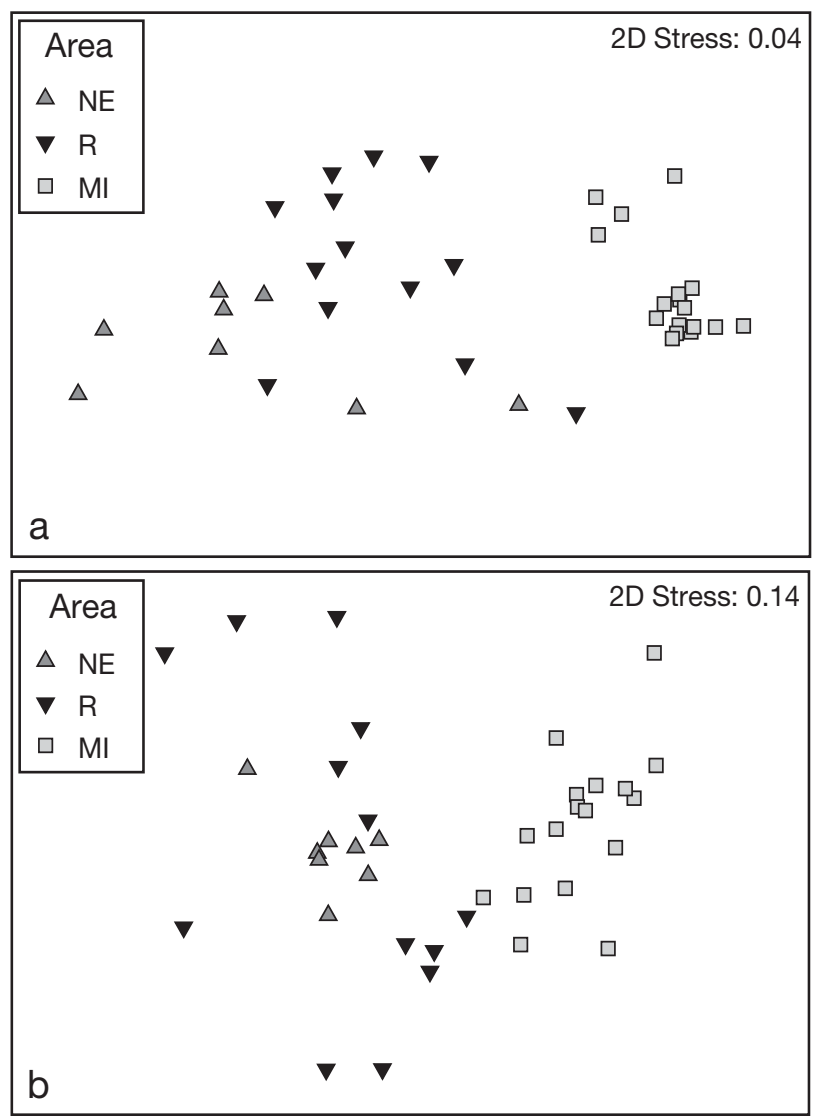

Fig. 2. Lophelia pertusa. Multidimensional scaling plots of similarities in the abundances of fatty acid methyl esters (FAME) and/or fatty alcohols in the (a) wax ester fractions (FAME plus fatty alcohols) and (b) triglyceride fractions (FAME) of coral samples from 3 different geographical areas: New England Seamounts (NE), Rockall Bank (R) and the Mingulay reef complex (MI)

Table 2. Lophelia pertusa. Pairwise comparisons (ANOSIM) of fatty acid/alcohol signatures between wax ester and triglyceride fractions of samples collected from New England Seamounts, Rockall Bank and the Mingulay reef complex

\begin{tabular}{|lccccc|}
\hline Variables & \multicolumn{2}{c}{ Wax ester } & \multicolumn{2}{c|}{ Triglyceride } \\
& $\mathrm{r}$ & $\mathrm{p}$ & $\mathrm{r}$ & $\mathrm{p}$ \\
\hline New England and Rockall & 0.399 & $<0.05$ & 0.068 & 0.195 \\
New England and Mingulay & 0.977 & $<0.01$ & 0.891 & $<0.01$ \\
Rockall and Mingulay & 0.932 & $<0.01$ & 0.654 & $<0.01$ \\
& & & & & \\
\end{tabular}

In the triglyceride fractions, 22:1(n-11), 20:5(n-3) and 20:1(n-9) were in greater abundance in the Mingulay samples, while 18:1(n-9) was more prevalent in the New England and Rockall samples (Table 4). These 4 FAME contributed nearly $50 \%$ to the differences between the Mingulay samples and those from New 
Table 3. Lophelia pertusa. SIMPER analysis of the fatty acid methyl esters and fatty alcohols (as trimethylsilylated [TMS] ethers) in the wax ester fractions that contribute to at least $50 \%$ of the differences between the fatty acid signatures of samples collected from New England Seamounts and Mingulay reef complex, Rockall Bank and Mingulay reef complex, and New England Seamounts and Rockall Bank

\begin{tabular}{|c|c|c|c|c|c|c|}
\hline \multirow{2}{*}{$\begin{array}{l}\text { Variable } \\
\text { New England vs. Mingulay }\end{array}$} & \multicolumn{2}{|c|}{ Means } & \multirow{2}{*}{$\begin{array}{c}\text { Average } \\
\text { dissimilarity }\end{array}$} & \multirow[t]{2}{*}{$\mathrm{SD}$} & \multirow[t]{2}{*}{$\%$ contribution } & \multirow[t]{2}{*}{ Cumulative $\%$} \\
\hline & & & & & & \\
\hline $18: 1(n-9)$ & 19.57 & 6.65 & 6.78 & 2.60 & 18.03 & 18.03 \\
\hline TMS 22:1 & 12.64 & 24.74 & 6.35 & 2.96 & 16.89 & 34.92 \\
\hline $22: 1$ & 5.72 & 13.52 & 4.09 & 3.03 & 10.88 & 45.81 \\
\hline TMS 20:1 & 5.23 & 13.00 & 4.09 & 5.06 & 10.86 & 56.67 \\
\hline \multicolumn{7}{|c|}{ Rockall vs. Mingulay } \\
\hline TMS 22:1 & 16.62 & 24.74 & 4.26 & 2.69 & 14.79 & 14.79 \\
\hline $22: 1$ & 6.34 & 13.52 & 3.77 & 3.22 & 13.09 & 27.88 \\
\hline $18: 1(n-9)$ & 12.84 & 6.65 & 3.25 & 1.76 & 11.29 & 39.17 \\
\hline TMS 16:0 & 12.51 & 6.37 & 3.22 & 2.62 & 11.18 & 50.35 \\
\hline \multicolumn{7}{|c|}{ New England vs. Rockall } \\
\hline 18:1(n-9) & 19.57 & 12.84 & 3.98 & 1.62 & 18.07 & 18.07 \\
\hline TMS 22:1 & 12.64 & 16.62 & 2.50 & 1.36 & 11.38 & 29.45 \\
\hline TMS 16:0 & 13.79 & 12.51 & 1.90 & 1.43 & 8.64 & 38.08 \\
\hline TMS 20:1 & 5.23 & 8.59 & 1.79 & 1.74 & 8.13 & 46.22 \\
\hline 20:5(n-3) & 3.00 & 4.27 & 1.45 & 1.82 & 6.57 & 52.78 \\
\hline
\end{tabular}

Table 4. Lophelia pertusa. SIMPER analysis of the fatty acid methyl esters in the triglyceride fractions contributing to at least $50 \%$ of the difference between the fatty acid signatures of samples collected from New England Seamounts and the Mingulay reef complex, and Rockall Bank and the Mingulay reef complex

\begin{tabular}{|c|c|c|c|c|c|c|}
\hline Variable & \multicolumn{2}{|c|}{ Means } & Average & $\mathrm{SD}$ & $\%$ contribution & Cumulative $\%$ \\
\hline \multicolumn{7}{|c|}{ New England vs. Mingulay } \\
\hline $22: 1(\mathrm{n}-11)$ & 3.15 & 9.91 & 4.08 & 2.39 & 15.59 & 15.59 \\
\hline $18: 1(n-9)$ & 7.18 & 2.00 & 2.97 & 5.74 & 11.34 & 26.94 \\
\hline $20: 1(n-9)$ & 2.74 & 7.38 & 2.66 & 2.77 & 10.19 & 37.12 \\
\hline $20: 5(n-3)$ & 11.42 & 13.20 & 1.80 & 1.25 & 6.88 & 44.00 \\
\hline $22: 1(n-9)$ & 3.98 & 1.99 & 1.70 & 1.98 & 6.50 & 50.50 \\
\hline \multicolumn{7}{|c|}{ Rockall vs. Mingulay } \\
\hline $22: 1(n-11)$ & 2.91 & 9.91 & 4.32 & 2.29 & 15.45 & 15.45 \\
\hline $20: 5(n-3)$ & 8.83 & 13.20 & 4.13 & 1.39 & 14.76 & 30.21 \\
\hline 18:1(n-9) & 6.74 & 2.00 & 2.80 & 1.36 & 10.01 & 40.22 \\
\hline 20:1(n-9) & 3.29 & 7.38 & 2.43 & 2.27 & 8.67 & 48.90 \\
\hline $16: 0$ & 13.71 & 14.17 & 1.98 & 0.88 & 7.07 & 55.97 \\
\hline
\end{tabular}

England and Rockall. There were no significant differences between the lipid signatures of New England and Rockall samples in this fraction.

\section{DISCUSSION}

\section{Seasonal analysis of the lipid signature of Lophelia pertusa}

The amounts of the 2 lipid classes, wax esters and triglycerides, and the relative proportions of lipids showed no seasonal variation in the samples from Mingulay taken in February, May, July and November.
Seasonal variations of lipid signatures in other marine invertebrates have previously been attributed to variations in the distribution of prey species (Cripps et al. 1999, Taylor \& Savage 2006) and PUFA in particular have been seen to vary with the reproductive cycle (Pond et al. 1996, Rosa \& Nunes 2002, 2003). A similar pattern might have been predicted for Lophelia pertusa since seasonal inputs of phytodetritus and copepods have been recorded in spring and summer months in areas where it occurs (Duineveld et al. 2004, Kiriakoulakis et al. 2004). In addition, L. pertusa from the Porcupine Seabight shows seasonality in reproduction, with the onset of gametogenesis in July and predicted release of gametes in January or February (Waller \& Tyler 2005). 
However, within the lipid fractions there were some differences in the degree of fatty acid saturation between months. In the wax ester fraction, the amount of MUFA differed between months, with the lowest observed in July. In the triglyceride fraction, SFA and MUFA also varied between months. The lower MUFA values in July could be linked to the low availability of MUFA-rich copepods before they become more abundant in the late summer or autumn, but the differences between months do not follow a clear pattern. It is therefore difficult to determine whether these differences are due to variations in food supply or seasonal variations in metabolism.

The lack of an obvious seasonal pattern could be explained if Lophelia pertusa is able to modify its metabolism throughout the year in relation to food availability, as observed in Antarctic invertebrates (Peck et al. 1997, Brockington \& Peck 2001, Fraser et al. 2002). If growth and respiration rates are lower in winter months, lipid levels could be maintained at near-constant levels throughout the year, despite a lower winter food input. Laboratory studies of L. pertusa respiration at different temperatures show its metabolic rate decreases dramatically with ambient temperature over the range experienced in the field (Dodds et al. 2007).

The present study focused on storage lipids in order to investigate food sources; however, future studies investigating seasonality should also include phospholipids and sterols because of their likely role in reproduction. Furthermore, studies of all lipid classes of Lophelia pertusa throughout seasonal cycles and in a number of locations would be required to produce a definitive seasonality study. These should be combined with histological studies of reproductive ecology and further investigation of seasonality in both food sources and metabolism.

\section{Lipid signature of Lophelia pertusa}

The tissue of Lophelia pertusa contained relatively large amounts of storage lipids, ranging from 5 to $12 \%$ of the AFDM of tissue, with the higher values recorded from the Mingulay reef complex. The upper end of the range is similar to levels of total lipids recorded in temperate anemones (10 to $13 \%$; Harland et al. 1992b) and tropical scleractinians in the Red Sea (11 to $17 \%$; Harland et al. 1993). These values are lower, however, than those recorded for Caribbean tropical scleractinians (24 to $35 \%$; Harland et al. 1992a). The highest proportion of storage lipids was found in samples from Mingulay (12\%) compared to those from Rockall (7\%) and the New England Seamounts (5\%). This could suggest a greater input of lipid-rich prey species and a strong link to surface production at the shallowest site examined, the Mingulay reef complex.

However, even at the deeper sites, Lophelia pertusa has a high lipid content derived from surface production. Particulate organic matter (POM) from deeper water sites in Rockall and Porcupine Seabight contained significant levels of PUFA, suggesting a strong link to surface production, albeit with variation between sites (Kiriakoulakis et al. 2007). Duineveld et al. (2004) also found a strong link to surface production at a cold-water coral area on the Galicia Bank (NW Spain), where they recorded phytodetritus as well as species of copepods and amphipods collected in nearbottom sediment traps. Variations in the metabolic requirements of corals at different depths could also cause differences in lipid storage within their tissue, reinforcing the need to study metabolism of corals collected from contrasting environments and depths. To date, only Dodds et al. (2007) have investigated respiratory physiology in $L$. pertusa using corals from just one area, the Mingulay reef complex.

In the present study, wax esters dominated the storage lipid signatures of Lophelia pertusa at all 3 study areas. This may imply dependence on wax ester-rich copepods since herbivorous calanoid copepods from high latitudes store large quantities of lipids as wax esters (Lee et al. 1971). L. pertusa contained an average of $62 \%$ wax ester, with the highest percentage in the Mingulay samples (69\%). In contrast, shallowwater azooxanthellate corals typically have lower levels of wax esters and a diet more directly dependent on phytoplankton (Patton et al. 1983, Latyshev et al. 1991, Yamashiro et al. 1999). Our understanding of coldwater coral metabolism is very limited and there is the possibility that L. pertusa could biosynthesise some fatty acids or fatty alcohols rather than obtaining them through the diet. For this reason results are interpreted cautiously.

As well as having significant proportions of wax ester, Lophelia pertusa had high proportions of MUFA, including the fatty acids 22:1 and 20:1 and their fatty alcohols. Calanoid copepods are the only organisms known to synthesise 22:1 and 20:1 fatty acids and alcohols de novo (Dalsgaard et al. 2003), suggesting that $L$. pertusa preys on these species. In contrast, shallowwater Tubastrea species had higher levels of PUFA than $L$. pertusa, although the composition was similar, including 20:5(n-3), 22:5(n-3) and 20:4(n-6) (Latyshev et al. 1991). This high proportion of PUFA and the low MUFA content - other than 18:1(n-9) - led Latyshev et al. (1991) to suggest that Tubastrea fed mainly on phytoplankton. Our findings indicate that L. pertusa is more carnivorous than these shallow-water azooxanthellate scleractinians. The lipid signature of L. pertusa is similar to the deep-sea suspension-feeding asteroids 
Freyella elegans, Brisingella coronata and Brisinga endecacnemos, which all contain high levels of PUFA as well as the copepod markers 20:1 and 22:1, suggesting a diet linked to the bentho-pelagic food web with copepods as an important prey item (Howell et al. 2003).

Both the present study and that of Kiriakoulakis et al. (2005) report high proportions of PUFA and MUFA in Lophelia pertusa. Kiriakoulakis et al. (2005) recorded a value of 1.13 for the relative abundance of PUFA divided by the relative abundance of MUFA. Our results show the equivalent value in the triglyceride fraction was similar (1.3), but was much lower in the wax ester fraction (0.2). Therefore, it seems that by not separating lipid classes, Kiriakoulakis et al. (2005) underestimated the importance of MUFA in the wax ester fraction. However, they did note the relatively large proportions of MUFA and, together with the difference in the ratio of the PUFA 22:6/20:5 between the corals and the sampled SPOM, suggested a mesozooplankton food source for $L$. pertusa. The present study reveals dominance of wax esters and high levels of MUFA in L. pertusa, suggesting significant food input from copepod species.

\section{Geographical variations in lipid signature}

The storage lipid signature of Lophelia pertusa varied between sites, suggesting possible differences in diet between samples from the shallow Mingulay Reef Complex and the deeper Rockall and New England Seamount sites. The different sites are likely to experience differences in conditions that could affect the lipid signature of potential prey and therefore could explain differences in the $L$. pertusa lipid profile. The mean temperature at the Mingulay site was $9.6^{\circ} \mathrm{C}$, with a similar mean of $9^{\circ} \mathrm{C}$ at Rockall and a somewhat lower mean temperature of $4.7^{\circ} \mathrm{C}$ at the New England Seamounts. The similarity in lipid profile between L. pertusa at the Rockall and New England sites, despite the temperature differences, suggests that temperature is not the most important factor in determining lipid content of food supplied.

There are a number of lines of evidence that suggest differences in prey sources between the different sites. Firstly, Lophelia pertusa from Mingulay showed high levels of calanoid copepod lipid biomarkers: the MUFA 22:1 and 20:1 and their fatty alcohols. Together these fatty acids and their associated alcohols contributed $>40 \%$ to the differences in the wax ester fraction between Mingulay samples and those from New England and Rockall. These fatty acids and alcohols were also present in the Rockall and New England samples, though in smaller proportions. Herbivorous calanoid copepods therefore may be a more important prey species for $L$. pertusa at the Mingulay reef complex compared with the deeper offshore bank and seamount sites.

In contrast, the storage lipid signature of Lophelia pertusa from New England and Rockall, with a high prevalence of the fatty acid 18:1(n-9) and the fatty alcohol 16:0, suggests greater dependence on omnivorous or carnivorous non-calanoid copepods compared to corals from Mingulay (Table 5). The 16:0 fatty alcohol is prominent in most copepods but tends to be more prevalent in non-calanoid species (e.g. Metridia longa) or in euphausids (e.g. Thysanoessa inermis), than in calanoid copepods (e.g. Calanus finmarchicus and $C$. hyperboreus) (Sargent \& Falk-Petersen 1981, 1988). The lipids of non-calanoid copepods are dominated by fatty acid 18:1(n-9) and fatty alcohols 14:0 and 16:0 (Kattner et al. 2003). These fatty acids and alcohols tend to indicate omnivorous or carnivorous feeding modes (Sargent \& McIntosh 1974).

Other differences included higher proportions of PUFA 20:5(n-3) in Lophelia pertusa from New England and Rockall compared with Mingulay. This PUFA comes from phytoplankton and is often found in herbivorous copepods, where it is an important component of structural membranes (Albers et al. 1996, Graeve et al. 1997, Kattner et al. 2003). It is often recorded with PUFA 22:6(n-3), which was present in L. pertusa from all areas in the present study, but in lower quantities. The low 22:6(n-3)/20:5(n-3) ratio we observed suggests that these PUFA may originate from diatoms rather than from dinoflagellates, and is similar to the

Table 5. Lophelia pertusa, Oithona similis and Calanus finmarchicus. Relative proportions (\%) of the dominant fatty alcohols and fatty acids found in L. pertusa from 3 different areas (Mingulay, Rockall and New England Seamounts; present study), a non-calanoid copepod $O$. similis (Kattner et al. 2003) and a calanoid copepod C. finmarchicus (Sargent \& Falk-Petersen 1988)

\begin{tabular}{|c|c|c|c|c|c|}
\hline \multirow[b]{2}{*}{ Lipid } & \multicolumn{3}{|c|}{ Lophelia pertusa } & \multirow{2}{*}{$\begin{array}{l}\text { Oithona } \\
\text { similis }\end{array}$} & \multirow{2}{*}{$\begin{array}{c}\text { Calanus } \\
\text { finmarchicus }\end{array}$} \\
\hline & Mingulay & Rockall & New England & & \\
\hline \multicolumn{6}{|l|}{ Alcohols } \\
\hline $14: 0$ & 0.9 & 3.5 & 3.4 & 23.7 & 6.4 \\
\hline 16:0 & 6.4 & 12.5 & 13.8 & 71.9 & 17.8 \\
\hline $20: 1(n-9)$ & 7.5 & 6.1 & 5.0 & 4.3 & 40.5 \\
\hline $22: 1(n-11)$ & 18.8 & 10.6 & 8.3 & - & 17.7 \\
\hline \multicolumn{6}{|l|}{ Fatty acids } \\
\hline 18:1(n-9) & 1.9 & 12.8 & 19.6 & 7.2 & 4.5 \\
\hline $20: 1(n-9)$ & 6.7 & 3.8 & 2.7 & 0.1 & 8.9 \\
\hline $22: 1(n-11)$ & 10.1 & 5.2 & 4.2 & - & 11.8 \\
\hline
\end{tabular}


ratio recorded for Lophelia pertusa by Kiriakoulakis et al. (2005). The presence of 20:5(n-3) alone cannot indicate whether this fatty acid originates directly from diatoms or whether it is conserved in herbivorous mesozooplankton prey. The ratio of 22:6(n-3)/20:5(n-3) recorded by Kiriakoulakis et al. (2005) differed from that of SPOM collected from the Porcupine Seabight, suggesting herbivorous zooplankton as the likely origin.

Finally, the MUFA 18:1(n-9) was more abundant in Lophelia pertusa from New England and Rockall than Mingulay. The ratio of 18:1(n-9)/18:1(n-7) can reflect both feeding mode and trophic level (Graeve et al. 1997). The high ratio from New England and Rockall implies a more carnivorous than herbivorous diet at these deeper sites.

\section{Distribution of copepod species}

Further studies on the lipid signatures of zooplankton samples collected at the study sites would be useful to support the data from Lophelia pertusa lipid analysis. This was not possible in the present study, but the data presented here will be extremely useful for future studies of zooplankton lipid profiles in coldwater coral areas. The lipid analysis of L. pertusa suggested that there may be differences in copepod prey between Mingulay and the 2 deeper sites, New England and Rockall, and it is possible that this could relate to the distribution of copepod species. High concentrations of non-calanoid copepods are found in shelf regions (Paffenhöfer et al. 1987): in older, upwelled water on the southeast continental shelf of the USA (Paffenhöfer 1993), on the Cape Hatteras shelf (Verity et al. 1996) and in the Porcupine Seabight to the west of Ireland (Hillgruber et al. 1997). The importance of small non-calanoid copepods in zooplankton communities has recently received increasing attention (Turner 2004). Despite their small size, the high abundance of non-calanoid copepods (e.g. Oithonidae) can produce an equivalent biomass to that of calanoid species.

The geographical variation of Arctic amphipod species may relate to the feeding preference of certain species for calanoid copepods, while others prefer to feed upon omnivorous or carnivorous copepods found in greater abundance in deeper waters (Auel et al. 2002). This implies that copepod species vary with depth and consumers will exploit the species present at different locations and depths. Therefore, it seems possible that the difference in depth between areas where Lophelia pertusa was sampled in the present study could explain the differences in copepod prey species.
The abundance and biomass of zooplankton is dependent on phytoplankton abundance and therefore tends to decrease with depth (Angel \& Baker 1982). In situ measurements at the Mingulay reef complex have shown that fluorescent surface water is rapidly transferred to the reefs during tidal-period downwelling events (Davies et al. 2009). This strong link to surface production at the relatively shallow Mingulay site is likely to result in greater abundance of herbivorous copepod species, whereas the deeper sites of Rockall and New England may have a reduced input of surface production and more omnivorous and/or carnivorous copepod species. Lophelia pertusa from New England and Rockall also had lower lipid levels, suggesting lower total food input to these areas compared with Mingulay. The lack of a seasonal pattern in storage lipid signature at Mingulay suggests seasonality is not a factor in the differences in storage lipid levels between sites.

There are no published studies on the plankton species of the Sea of the Hebrides, where the Mingulay reef complex is found. However, a long-term fjordic monitoring programme in Loch Ewe on the west coast of Scotland has recorded high numbers of calanoid copepods, especially Calanus helgolandicus, which occurs mainly in the late summer (FRS 2007). C. finmarchicus was also present in lower numbers, as were small calanoid species and small non-calanoid (cyclopoid) copepods, including Oithona species (FRS 2007). When plankton species on the west coast of Scotland were compared geographically, large oceanic calanoid species became more abundant with increasing distance from the coast (Mauchline 1987). It is therefore possible that zooplankton populations around the Mingulay reef complex contain more oceanic calanoid species than the coastal waters of Loch Ewe. These species are potentially important prey for Lophelia pertusa at Mingulay and likely contribute to high levels of wax esters and calanoid copepod lipid biomarkers.

\section{CONCLUSIONS}

The fatty acid composition of Lophelia pertusa implies a link to surface production. Copepod species appear to be a dominant food source and the geographical variations in storage lipid signature are likely to be related to variations in copepod prey species. The reduced storage lipid levels in New England and Rockall corals could imply differences in food availability and metabolism. It is therefore likely that $L$. pertusa is an opportunistic feeder able to exploit the dominant copepod species in a particular area. In recent years, changes in the distribution of copepods have been observed and related to increased 
seawater temperature caused by climate change (Reid et al. 1998, Beaugrand et al. 2002, Beaugrand \& Reid 2003). L. pertusa shows dramatic increases in respiration rate with relatively small changes in temperature (Dodds et al. 2007). It is possible that the current prey species of L. pertusa in particular areas will change in the coming decades. Further biomarker and feeding trial studies are needed to investigate how dependent $L$. pertusa is on the prey species identified in the present study and how adaptable this habitat-forming coral may be to future changes in seawater temperature and zooplankton distribution.

Acknowledgements. This work formed part of L.A.D.'s PhD research funded by the UK Natural Environment Research Council (PhD grant no. NER/S/A/2003/11898) and was further supported by the HERMES project (EC contract no. GOCE-CT-2005-511234) funded by the European Commission's Sixth Framework Programme under the priority 'Sustainable Development, Global Change and Ecosystems' and the TRACES project (EC contract no. MOIF-CT-2006-040018) under the programme 'Structuring the European Research Area'. We are grateful to comments from 3 anonymous reviewers that have greatly improved the manuscript. We also thank D. Santillo and the Greenpeace crew of MY 'Esperanza' and the SAMS crew of RV 'Calanus' for assistance with live coral sampling. We are grateful to R. Waller (North Atlantic Stepping Stones cruise) and crew of the NOAA ship 'Ronald H. Brown' for collecting New England Seamount samples. Thanks also to A. Davies, G. Duineveld and the crew of RV 'Pelagia' (cruise 64PE 249) for collecting Logachev mound samples.

\section{LITERATURE CITED}

Albers CS, Kattner G, Hagen W (1996) The compositions of wax esters, triacylglycerols and phospholipids in Arctic and Antarctic copepods: evidence of energetic adaptations. Mar Chem 55:347-358

Angel MV, Baker AC (1982) Vertical distribution of the standing crop of plankton and micronekton at three stations in the northeast Atlantic. Biol Oceanogr 2:1-30

Auel H, Harjes M, da Rocha R, Stubing D, Hagen W (2002) Lipid biomarkers indicate different ecological niches and trophic relationships of the Arctic hyperiid amphipods Themisto abyssorum and $T$. libellula. Polar Biol 25: 374-383

Beaugrand G, Reid PC (2003) Long-term changes in phytoplankton, zooplankton and salmon related to climate. Glob Change Biol 9:801-817

Beaugrand G, Reid PC, Ibanez F, Lindley JA, Edwards M (2002) Reorganization of North Atlantic marine copepod biodiversity and climate. Science 296:1692-1694

Best NJ, Bradshaw CJA, Hindell MA, Nichols PD (2003) Vertical stratification of fatty acids in the blubber of southern elephant seals (Mirounga leonina): implications for diet analysis. Comp Biochem Physiol B 134:253-263

Brockington S, Peck LS (2001) Seasonality of respiration and ammonium excretion in the Antarctic echinoid Sterechinus neumayeri. Mar Ecol Prog Ser 219:159-168

Christie WW (2003) Lipid analysis: isolation, separation, identification and structural analysis of lipids. The Oily Press, Dundee
Cook EJ, Bell MV, Black KD, Kelly MS (2000) Fatty acid compositions of gonadal material and diets of the sea urchin, Psammechinus miliaris: trophic and nutritional implications. J Exp Mar Biol Ecol 255:261-274

Cripps GC, Watkins JL, Hill HJ, Atkinson A (1999) Fatty acid content of Antarctic krill Euphausia superba at South Georgia related to regional populations and variations in diet. Mar Ecol Prog Ser 181:177-188

> Dalsgaard J, St John M, Kattner G, Muller-Navarra D, Hagen W (2003) Fatty acid trophic markers in the pelagic marine environment. Adv Mar Biol 46:225-340

> Davies AJ, Wisshak M, Orr JC, Roberts JM (2008) Predicting suitable habitat for the cold-water coral Lophelia pertusa (Scleractinia). Deep-Sea Res I 55:1048-1062

Davies AJ, Duineveld GCA, Lavaleye MSS, Bergman MJN, Van Haren H, Roberts JM (2009) The importance of particle-rich downward water motion and bottom water advection as food supply mechanisms to the cold-water coral Lophelia pertusa (Scleractinia) at the Mingulay Reef Complex. Limnol Oceanogr 54:620-629

> Dodds LA, Roberts JM, Taylor AC, Marubini F (2007) Metabolic tolerance of the cold-water coral Lophelia pertusa (Scleractinia) to temperature and dissolved oxygen change. J Exp Mar Biol Ecol 349:205-214

> Duineveld GCA, Lavaleye MSS, Berghuis EM (2004) Particle flux and food supply to a seamount cold-water coral community (Galicia Bank, NW Spain). Mar Ecol Prog Ser 277: $13-23$

Duineveld GCA, Lavaleye M, Bergman M, Witbaard R and others (2006) Biodiversity, ecosystem functioning and food web complexity of cold water coral reefs in the NE Atlantic (Rockall Bank). Hermes 2006 Cruise Report. Royal Netherlands Institute for Sea Research, Texel

Duineveld GCA, Lavaleye MSS, Bergman MJN, de Stigter H, Mienis F (2007) Trophic structure of a cold-water coral mound community (Rockall Bank, NE Atlantic) in relation to the near-bottom particle supply and current regime. Bull Mar Sci 81:449-467

> Falk-Petersen S, Gatten RR, Sargent JR, Hopkins CCE (1981) Ecological investigations on the zooplankton community in Balsfjorden, Northern Norway: seasonal changes in the lipid class composition of Meganyctiphanes norvegica (M. Sars), Thysanoessa raschii (M. Sars), and T. inermis (Kroyer). J Exp Mar Biol Ecol 54:209-224

Falk-Petersen S, Sargent JR, Tande KS (1987) Lipid composition of zooplankton in relation to the sub-Arctic food web. Polar Biol 8:115-120

Feller RJ, Zagursky G, Day EA (1985) Deep-sea food web analysis using cross-reacting antisera. Deep-Sea Res A 32: 485-497

Fraser KPP, Clarke A, Peck LS (2002) Feast and famine in Antarctica: seasonal physiology in the limpet Nacella concinna. Mar Ecol Prog Ser 242:169-177

FRS (Fisheries Research Services) (2007) Stonehaven/Loch Ewe ecosystem monitoring. Available at www.frs-scotland.gov.uk/Delivery/standalone.aspx? contentid=1144

> Graeve M, Kattner G, Piepenburg D (1997) Lipids in Arctic benthos: Does the fatty acid and alcohol composition reflect feeding and trophic interactions? Polar Biol 18: $53-61$

> Guinotte JM, Orr J, Cairns S, Freiwald A, Morgan L, George R (2006) Will human-induced changes in seawater chemistry alter the distribution of deep-sea scleractinian corals? Front Ecol Environ 4:141-146

Harland AD, Fixter LM, Davies PS, Anderson RA (1991) Distribution of lipids between the zooxanthellae and animal compartment in the symbiotic sea anemone Anemo- 
nia viridis: wax esters, triglycerides and fatty acids. Mar Biol 110:13-19

Harland AD, Davies PS, Fixter LM (1992a) Lipid content of some Caribbean corals in relation to depth and light. Mar Biol 113:357-361

Harland AD, Fixter LM, Davies PS, Anderson RA (1992b) Effect of light on the total lipid content and storage lipids of the symbiotic sea anemone Anemonia viridis. Mar Biol 112:253-258

Harland AD, Navarro JC, Davies PS, Fixter LM (1993) Lipids of some Caribbean and Red Sea corals: total lipid, wax esters, triglycerides and fatty acids. Mar Biol 117:113-117

Henrich R, Freiwald A, Shipboard Party (1997) Lophelia reef on Sula Ridge, mid-Norwegian shelf. Cruise Report No. 228/97, IFM-GEOMAR, Kiel

> Hillgruber N, Kloppmann M, Wahl E, von Westernhagen H (1997) Feeding of larval blue whiting and Atlantic mackerel: a comparison of foraging strategies. J Fish Biol 51: 230-249

> Howell KL, Pond DW, Billett DSM, Tyler PA (2003) Feeding ecology of deep-sea seastars (Echinodermata: Asteroidea): a fatty-acid biomarker approach. Mar Ecol Prog Ser 255: 193-206

Hudson IR, Pond DW, Billett DSM, Tyler PA, Lampitt RS, Wolff GA (2004) Temporal variations in fatty acid composition of deep-sea holothurians: evidence of benthopelagic coupling. Mar Ecol Prog Ser 281:109-120

Iverson SJ, Field C, Bowen WD, Blanchard W (2004) Quantitative fatty acid signature analysis: a new method of estimating predator diets. Ecol Monogr 74:211-235

Kattner G, Hagen W (1995) Polar herbivorous copepods: different pathways in lipid biosynthesis. ICES J Mar Sci 52: 329-335

Kattner G, Albers C, Graeve M, Schnack-Schiel SB (2003) Fatty acid and alcohol composition of the small polar copepods, Oithona and Oncaea: indication on feeding modes. Polar Biol 26:666-671

Kelly JR, Scheibling RE, Iverson SJ, Gagnon P (2008) Fatty acid profiles in the gonads of the sea urchin Strongylocentrotus droebachiensis on natural algal diets. Mar Ecol Prog Ser 373:1-9

Kenyon NH, Akhmetzhanov AM, Wheeler AJ, Van Weering T, De Haas H, Ivanov MK (2003) Giant carbonate mud mounds in the southern Rockall Trough. Mar Geol 195: 5-30

Kiriakoulakis K, Bett BJ, White M, Wolff GA (2004) Organic biogeochemistry of the Darwin Mounds, a deep-water coral ecosystem, of the NE Atlantic. Deep-Sea Res I 51: 1937-1954

Kiriakoulakis K, Fisher L, Freiwald A, Grehan A, Roberts JM, Wolff GA (2005) Lipids and nitrogen isotopes of two deepwater corals from the North-East Atlantic: initial results and implications for their trophic regime. In: Freiwald A, Roberts JM (eds) Cold-water corals and ecosystems. Springer, Berlin, p 715-729

Kiriakoulakis K, Freiwald A, Fisher E, Wolff GA (2007) Organic matter quality and supply to deep-water coral/mound systems of the NW European Continental Margin. Int J Earth Sci 96:159-170

> Latyshev NA, Naumenko NV, Svetashev VI, Latypov YY (1991) Fatty acids of reef-building corals. Mar Ecol Prog Ser 76:295-301

Lee RF, Nevenzel JC, Paffenhöfer GA (1971) Importance of wax esters and other lipids in marine food chain: phytoplankton and copepods. Mar Biol 9:99-108

> Mancini I, Guerriero A, Guella G, Bakken T, Zibrowius H, Pietra F (1999) Novel 10-hydroxydocosapolyenoic acids from deep-water scleractinian corals. Helv Chim Acta 82: 677-684

Masson DG, Bett BJ, Billett D, Jacobs CL, Wheeler AJ, Wynn RB (2003) The origin of deep-water, coral-topped mounds in the northern Rockall Trough, Northeast Atlantic. Mar Geol 194:159-180

Mauchline J (1987) Zooplankton in the Oban area and especially in upper Loch Etive. Internal Report No. 144, Scottish Association for Marine Science, Oban

Meyers PA (1979) Polyunsaturated fatty acids in coral: indicators of nutritional sources. Mar Biol Lett 1:69-75

Mortensen PB, Hovland M, Fossa JH, Furevik DM (2001) Distribution, abundance and size of Lophelia pertusa coral reefs in mid-Norway in relation to seabed characteristics. J Mar Biol Assoc UK 81:581-597

Muscatine L, Porter JW, Kaplan IR (1989) Resource partitioning by reef corals as determined from stable isotope composition. I. $\%{ }^{13} \mathrm{C}$ of zooxanthellae and animal tissue vs depth. Mar Biol 100:185-193

Ohman MD (1996) Freezing and storage of copepod samples for the analysis of lipids. Mar Ecol Prog Ser 130:295-298

> Omata T, Suzuki A, Sato T, Minoshima K and others (2008) Effect of photosynthetic light dosage on carbon isotope composition in the coral skeleton: long-term culture of Porites spp. J Geophys Res 113:G02014

Paffenhöfer GA (1993) On the ecology of marine cyclopoid copepods (Crustacea, Copepoda). J Plankton Res 15:37-55

Paffenhöfer GA, Sherman BK, Lee TN (1987) Summer upwelling on the southeastern continental shelf of the USA during 1981. Abundance, distribution and patch formation of zooplankton. Prog Oceanogr 19:403-436

Papina M, Mezaine T, van Woesik R (2003) Symbiotic zooxanthellae provide the host coral Montipora digitata with polyunsaturated fatty acids. Comp Biochem Physiol B 135: 533-537

> Patton JS, Abraham S, Benson AA (1977) Lipogenesis in the intact coral Pocillopora capitata and its isolated zooxanthellae: evidence for a light-driven carbon cycle between symbiont and host. Mar Biol 44:235-247

Patton JS, Battey JF, Rigler MW, Porter JW, Black CC, Burris JE (1983) A comparison of the metabolism of bicarbonate ${ }^{14} \mathrm{C}$ and acetate $1-{ }^{14} \mathrm{C}$ and the variability of species lipid compositions in reef corals. Mar Biol 75:121-130

Peck LS, Brockington S, Brey TA (1997) Growth and metabolism in the Antarctic brachiopod Liothyrella uva. Philos Trans R Soc Lond B Biol Sci 352:851-858

Pond D, Harris R, Head R, Harbour D (1996) Environmental and nutritional factors determining seasonal variability in the fecundity and egg viability of Calanus helgolandicus in coastal waters off Plymouth, UK. Mar Ecol Prog Ser 143: 45-63

Reid PC, Planque B, Edwards M (1998) Is observed variability in the long-term results of the Continuous Plankton Recorder survey a response to climate change? Fish Oceanogr 7:282-288

Reynaud-Vaganay S, Juillet-Leclerc A, Jaubert J, Gattuso JP (2001) Effect of light on skeletal $\delta^{13} \mathrm{C}$ and $\delta^{18} \mathrm{O}$, and interaction with photosynthesis, respiration and calcification in two zooxanthellate scleractinian corals. Palaeogeogr Palaeoclimatol Palaeoecol 175:393-404

- Roberts JM, Anderson RM (2002) A new laboratory method for monitoring deep-water coral polyp. Hydrobiologia 471: 143-148

> Roberts JM, Brown CJ, Long D, Bates CR (2005) Acoustic mapping using a multibeam echosounder reveals coldwater coral reefs and surrounding habitats. Coral Reefs $24: 654-669$ 
Roberts JM, Wheeler AJ, Freiwald A (2006) Reefs of the deep: the biology and geology of cold-water coral ecosystems. Science 312:543-547

Roberts JM, Wheeler AJ, Freiwald A, Cairns S (2009) Coldwater corals: the biology and geology of deep-sea coral habitats. Cambridge University Press, Cambridge

Roberts JM, Davies AJ, Henry LA, Duineveld GCA and others (2009) Mingulay reef complex, northeast Atlantic: an interdisciplinary study of cold-water coral habitat, hydrography and biodiversity. Mar Ecol Prog Ser 397: 139-151

Rosa R, Nunes ML (2002) Biochemical changes during the reproductive cycle of the deep-sea decapod Nephrops norvegicus on the south coast of Portugal. Mar Biol 141: 1001-1009

Rosa R, Nunes ML (2003) Tissue biochemical composition in relation to the reproductive cycle of deep-sea decapod Aristeus antennatus in the Portuguese south coast. J Mar Biol Assoc UK 83:963-970

Sargent JR, Falk-Petersen S (1981) Ecological investigations on the zooplankton community in Balsfjorden, northern Norway: lipids and fatty acids in Meganyctiphanes norvegica, Thysanoessa raschi and T. inermis during midwinter. Mar Biol 62:131-137

Sargent JR, Falk-Petersen S (1988) The lipid biochemistry of calanoid copepods. Hydrobiologia 167-168:101-114

Sargent JR, McIntosh R (1974) Studies on mechanism of biosynthesis of wax esters in Euchaeta norvegica. Mar Biol 25:271-277

Sargent JR, Whittle KJ (1981) Lipids and hydrocarbons in the marine food web. In: AR Longhurst (ed) Analysis of marine ecosystems. Academic Press, London, p 431-533

Spitzer V (1996) Structure analysis of fatty acids by gas chromatography - low resolution electron impact mass spec-

Submitted: January 27, 2009; Accepted: June 4, 2009 trometry of their 4,4-dimethyloxazoline derivatives-a review. Prog Lipid Res 35:387-408

Taylor AG, Savage C (2006) Fatty acid composition of New Zealand green-lipped mussels, Perna canaliculus: implications for harvesting for n-3 extracts. Aquaculture 261: 430-439

Treignier C, Grover R, Ferrier-Pages C, Tolosa I (2008) Effect of light and feeding on the fatty acid and sterol composition of zooxanthellae and host tissue isolated from the scleractinian coral Turbinaria reniformis. Limnol Oceanogr 53:2702-2710

Turner JT (2004) The importance of small planktonic copepods and their roles in pelagic marine food webs. Zool Stud 43:255-266

van Weering TCE, de Haas $\mathrm{H}$, de Stigter HC, Lykke-Andersen H, Kouvaev I (2003) Structure and development of giant carbonate mounds at the SW and SE Rockall Trough margins, NE Atlantic Ocean. Mar Geol 198:67-81

Verity PG, Paffenhofer GA, Wallace D, Sherr E, Sherr B (1996) Composition and biomass of plankton in spring on the Cape Hatteras shelf, with implications for carbon flux. Cont Shelf Res 16:1087-1116

- Waller RG, Tyler PA (2005) The reproductive biology of two deep-water, reef-building scleractinians from the NE Atlantic Ocean. Coral Reefs 24:514-522

White M, Mohn C, de Stigter H, Mottram G (2005) Deepwater coral development as a function of hydrodynamics and surface productivity around the submarine banks of the Rockall Trough, NE Atlantic. In: Freiwald A, Roberts JM (eds) Cold-water corals and ecosystems. Springer-Verlag, Berlin, p 503-514

> Yamashiro H, Oku H, Higa H, Chinen I, Sakai K (1999) Composition of lipids, fatty acids and sterols in Okinawan corals. Comp Biochem Physiol B 122:397-407

Proofs received from author(s): October 1, 2009 